\title{
Pomoc na ratowanie i restrukturyzację ZAGROŻONYCH PRZEDSIĘBIORSTW LOTNICZYCH - WYBRANE ZAGADNIENIA PRAWNE
}

\section{Wstęp}

Współcześnie mamy do czynienia z różnymi sposobami ratowania i restrukturyzacji zagrożonych przedsiębiorstw. Takie działania przeważnie wiążą się z pomocą państwa i zaburzeniami konkurencji na rynku ${ }^{1}$, dlatego tym bardziej istotne jest kontrolowanie wykorzystania udzielonej pomocy. Wbrew twierdzeniom niektórych, pomoc na ratowanie i restrukturyzację nie jest sposobem na zwiększenie aktywności gospodarczej, a ma na celu wdrożenie planu umożliwiającego taką zmianę modelu biznesowego, który pozwoli na funkcjonowanie przedsiębiorstwa w dłuższej perspektywie czasu bez konieczności sięgania po dalsze wsparcie finansowe państwa. Żeby uznać pomoc taką za legalna, konieczne jest uzyskanie pozytywnej decyzji Komisji Europejskiej i wdrożenie tzw. środków kompensacyjnych niwelujących negatywne skutki naruszenia konkurencji, którymi dotknięci mogą być konkurenci niekorzystający z tego rodzaju pomocy.

Celem artykułu jest przeanalizowanie przepisów prawa polskiego i Unii Europejskiej oraz pokazanie w jaki sposób są one stosowane w prak-

* Dr, Wyższa Szkoła Handlowa w Radomiu

** Dr, Polskie Linie Lotnicze LOT S.A.

${ }^{1}$ M. Bujnowski, Unijna polityka w zakresie zewnętrznych stosunków w dziedzinie lotnictwa, „Ikar” Internetowy Kwartalnik Antymonopolowy i Regulacyjny 2016, nr 2 (5), www.ikazr. wz.uw.edu.pl 
tyce w zakresie ratowania i restrukturyzacji zagrożonych przedsiębiorstw lotniczych. Artykuł posiada charakter badawczy, a analiza treści przepisów prawa i orzecznictwa wymagała zastosowania metody prawno - porównawczej. Postawiono $w$ nim następujący problem badawczy: $w$ jaki sposób przepisy prawa zapewniają pomoc na ratowanie i restrukturyzację zagrożonych przedsiębiorstw lotniczych, a problemami badawczymi szczegółowymi są:

Czy gwarantowane w przepisach prawa możliwości finansowania przewoźników lotniczych odpowiadają potrzebom przewoźników lotniczych, w tym przede wszystkim potrzebom przewoźników unijnych?

Czy Unia Europejska dąży do zapewnienia jednakowych zasad finansowania przewoźników wewnątrz UE i poza nią?

Już na wstępie przyjęto hipotezę główną, że międzynarodowy transport lotniczy potrzebuje jasnych i jednolitych instrumentów prawnych nie tylko w odniesieniu do finansowania przewoźników lotniczych, ale również międzynarodowych reguł prawnych, które zapewniłyby równe zasady konkurowania dla wszystkich przewoźników, bez względu na model prowadzonej działalności czy pochodzenie przewoźnika lotniczego.

Hipotezy szczegółowe wyodrębniono w sposób następujący:

1. Wypracowane rozwiązania regionalne ze szczególnym uwzględnieniem Unii Europejskiej nie stwarzają wystarczającej ochrony prawnej zapewniającej stabilność w funkcjonowaniu przewoźników lotniczych;

2. Przepisy prawa Unii Europejskiej wprowadzają nierówne zasady konkurowania przewoźników sieciowych i niskokosztowych.

\section{Stosowanie zasad ogólnych do przewoźników lotniczych}

Pogłębiająca się fala kryzysu, która dotknęła również linie lotnicze powoduje, że coraz częściej walczą one o przetrwanie i szukają środków na bieżące prowadzenie działalności. Paradoskalnie większość tych przewoźników nadal pozostaje własnością poszczególnych państw członkowskich. Truxal wskazuje, że na tym tle dochodzi do konfliktu, bo z jednej strony państwa członkowskie powinny zapewnić odpowiednie i stabilne środki transportu lotniczego przy jednoczesnym respektowaniu przepisów dotyczących udzielania pomocy publicznej, a z drugiej strony chcą 
realizować swoje wewnętrzne cele ${ }^{2}$. W chwili obecnej przed Komisją toczy się kilka postępowań w sprawie wyrażenia zgody na udzielenie pomocy w celu ratowania i restrukturyzacji aż siedmiu przewoźników unijnych. W ostatnim czasie Komisja zaaprobowała pomoc dla przewoźnika Polskie Linie Lotnicze LOT S.A. Każde z tych postępowań prowadzone jest niezależnie. W latach 1993-1994 tuż po wprowadzeniu trzeciego pakietu liberalizacyjnego Komisja masowo analizowała przypadki dofinansowywania linii lotniczych, a wśród nich Sabeny, Iberii, Aer Lingus, TAP Air Portugal, Air France, Olympic Airline, czy Alitalii ${ }^{3}$. Chociaż w prawie UE brak jest legalnej definicji przedsiębiorstwa zagrożonego, co często stwarza problemy natury interpretacyjnej, to za takie uznaje się przedsiębiorstwo, które ani przy pomocy środków własnych, ani środków, które mogłoby uzyskać od właścicieli/akcjonariuszy lub wierzycieli, nie jest w stanie powstrzymać strat, które bez zewnętrznej interwencji władz publicznych prawie na pewno doprowadziłyby to przedsiębiorstwo do zniknięcia z rynku w perspektywie krótko lub średnioterminowej. Odpowiedni komunikat w tym przedmiocie Komisja opublikowała w 1994 r. ${ }^{4}$. Podstawowym celem omawianej tutaj pomocy jest doprowadzenie do zachowania płynności finansowej przedsiębiorstwa na czas niezbędny dla opracowania planu restrukturyzacji lub likwidacji. Pomoc ta jest więc środkiem czasowym, ograniczonym do niezbędnego minimum. Nie powinna trwać dłużej niż 6 miesięcy i przede wszystkim powinna zakładać zwrotne wsparcie płynności finansowej i mieć formę gwarancji kredytowych lub pożyczek o stopie procentowej przynajmniej porównywalnej do pożyczek dla przedsiębiorstw w dobrej sytuacji finansowej. Przed upływem tego okresu państwo członkowskie musi albo zatwierdzić plan restrukturyzacji lub plan likwidacji, albo też zażądać od beneficjenta zwrotu pożyczki i pomocy odpowiadającej premii z tytułu ryzyka. Wszelka po-

2 S. Truxal, Competition and Regulation in the Airline Industry: Puppets in Chaos, Routledge 2012, str. 99

${ }^{3}$ Commission Decision 94/118/EC z 21 grudnia 1993r. concerning aid to be provided by the Irish Government to the Aer Lingus group, an undertaking mainly providing air transport services, Dz. Urz. UE L 054 z 25.02.1994, Commission Decision 94/698/EC z 6 lipca $1994 \mathrm{r}$. concerning increase in capital, credit guarantees and tax exemption in favour of TAP, Dz. Urz. UE L279 z 28.10.1994, Commission Decision 94/653 z dnia 27 lipca 1994r. concerning the notified capital increase of Air France, Dz. Urz. L254 z 30.09.1994, Commission Decision 94/696/EC z 7 października 1994 on the aid granted by Greece to Olympic Airways, Dz. Urz. UE L273 z 25.10.1994..

4 Wytyczne wspólnotowe dotyczące pomocy państwa w celu ratowania i restrukturyzacji zagrożonych przedsiębiorstwa, Dz. Urz. UE C 244/2 z dnia 1 października 2004 r. 
moc przyznana na okres dłuży niż 6 miesięcy bądź niezwrócona po upływie tego okresu musi być zgłoszona Komisji.

Kwota i intensywność pomocy muszą być ograniczone do ścisłego minimum kosztów restrukturyzacji, tak aby umożliwić podjęcie restrukturyzacji przy pomocy istniejących zasobów finansowych przedsiębiorstwa, jego akcjonariuszy lub grupy kapitałowej. Wytyczne Komisji przewiduja że pomoc ta uzależniona jest również od wkładu finansowego beneficjentów, włącznie ze sprzedażą aktywów, które z kolei nie są niezbędne do dalszego istnienia przedsiębiorstwa lub pomoc taka musi pochodzić z zewnętrznych źródeł finansowania i być udzielona na warunkach rynkowych, czyli takich, które dostępne są dla innych przedsiębiorstw nie znajdujących się w trudnej sytuacji finansowej.

Okres wdrożenia planu restrukturyzacji powinien być możliwie najkrótszy, a przede wszystkim powinien przywrócić długoterminową rentowność przedsiębiorstwa w rozsądnych ramach czasowych i na podstawie realistycznych założeń co do przyszłych warunków działania. Plan powinien zostać przedłożony Komisji i uwzględniać badanie rynku oraz inne istotne szczegóły. Lepsza rentowność przedsiębiorstwa musi wynikać ze środków wewnętrznych zawartych w planie restrukturyzacji i może opierać się o czynniki zewnętrzne, takie jak zmiany cen i zmiany popytu, na które przedsiębiorstwo nie ma większego wpływu, tylko jeżeli uczynione założenia rynkowe są ogólnie uznane. Co ważne, restrukturyzacja musi zakładać zaprzestanie wykonywania działalności, która nawet po restrukturyzacji przynosiłaby straty - oznacza to zatem, że od początku do końca musi zakładać rentowność prowadzonej przez przedsiębiorstwo działalności. W celu ograniczenia skutku zakłócającego konkurencję na rynku, ani kwota pomocy, ani tym bardziej forma, w której pomoc jest przyznawana - nie mogą stanowić dla przedsiębiorstwa nadwyżki, która mogłaby być wykorzystana do agresywnych działań zagrażających rynkowi, niezwiązanych z procesem restrukturyzacji. Żadna z przyznanej pomocy nie może zostać wykorzystana do finansowania nowych inwestycji, które nie mają związku z przywróceniem rentowności przedsiębiorstwa.

Komisja może uzależnić przyznanie pomocy od spełnienia przez przedsiębiorstwo innych warunków i obowiązków, jakie uzna za niezbędne dla zachowania konkurencji na rynku zgodnej z wspólnym interesem. Beneficjent pomocy musi w pełni wdrożyć plan restrukturyzacji oraz wykonać wszystkie inne zobowiązania ustanowione w decyzji Komisji zezwalającej na pomoc. W innym przypadku Komisja uzna każde takie 
zaniechanie we wdrożeniu planu lub w wypełnieniu pozostałych zobowiązań za nieprawidłowe wykorzystanie pomocy.

W celu zapewnienia pełnej kontroli nad prawidłowością udzielonej pomocy, państwa członkowskie zobowiązane są do systematycznego notyfikowania Komisji o podejmowanych działaniach związanych z wdrażaniem planu restrukturyzacji.

Zdaniem Komisji, nie jest wskazanym wielokrotne przyznawanie pomocy w celu ratowania, bo takie działania prowadzą do utrzymania status quo i odsuwają jedynie w czasie nieuniknione konsekwencje związane $\mathrm{z}$ trudną sytuacją finansową przed siębiorstwa. Pomoc na ratowanie przedsiębiorstw zagrożonych powinna być udzielona tylko pod warunkiem, że przewoźnik nie korzystał z żadnej innej formy pomocy publicznej. Chodzi przede wszystkim o zapobieżenie niesprawiedliwemu przyznawaniu pomocy przedsiębiorstwom, które mogą funkcjonować wyłącznie dzięki wielokrotnie udzielanym zastrzykom finansowym. Zdaniem Komisji, jeżeli pomoc na ratowanie udzielana jest podmiotowi, który już otrzymał pomoc na restrukturyzację, to można wnioskować, że problemy tego podmiotu mają charakter stały, a wielokrotne interwencje państwa powodują zakłócenia konkurencji, co jest sprzeczne ze wspólnym interesem. Jeśli zatem pomoc na ratowanie lub w celu restrukturyzacji otrzymała już grupa kapitałowa, to Komisja nie przyzna dalszej pomocy dla tej grupy ani żadnego podmiotu wchodzącego w jej skład przed upływem 10 lat od chwili przyznania pomocy lub od wstrzymania wdrażania planu restrukturyzacji, w zależności od tego, które z tych zdarzeń wystąpiło jako ostatnie.

Z indywidualnego informowania Komisji o udzielaniu pomocy na ratowanie i restrukturyzację zagrożonych przedsiębiorstw zwolnione są małe i średnie przedsiębiorstwa, wówczas gdy potencjalny beneficjent spełnia co najmniej jedno z trzech kryteriów przedsiębiorstwa zagrożonego. Co ważne, kryteria te odnoszą się do każdego z przedsiębiorstw - niezależnie od ich wielkości, ale zwolnionymi z obowiązku notyfikowania Komisji są w zasadzie tylko przedsiębiorstwa małe i średnie ${ }^{5}$ i to tylko wtedy, gdy

${ }^{5}$ Definicja małych i średnich przedsiębiorstw (MŚP) wprowadzona została na mocy rozporządzenia Komisji (WE) nr 800/2008 z dnia 6 sierpnia 2008 r. uznającego niektóre rodzaje pomocy za zgodne ze wspólnym rynkiem w zastosowaniu art. 87 i 88 Traktatu, Dz. Urz. UE L 214 z 9.08.2008 z 2008 r., 214/3. Kryteria dla tych przedsiębiorstw (MŚP) określone zostały $\mathrm{w}$ art. 2 załącznika nr 1 do tego rozporządzenia. Do kategorii mikroprzedsiębiorstw oraz małych i średnich przedsiębiorstw zalicza się przedsiębiorstwa, które zatrudniają mniej niż 250 pracowników i których roczny obrót nie przekracza $50 \mathrm{mln}$ EUR a/lub całkowity bilans roczny nie przekracza $43 \mathrm{mln}$ EUR. 
zasady ustanowione dla poszczególnych sektorów gospodarki nie stanowią inaczej. Natomiast pomoc dla pozostałych przedsiębiorstw, tj. przedsiębiorstw dużych i tych niespełniających przesłanek określonych w wytycznych dla przedsiębiorstw zagrożonych musi być zgłoszona Komisji. Ta z kolei ocenia, czy dane przedsiębiorstwo kwalifikuje się do uznania go za przedsiębiorstwo zagrożone.

Przy ocenie działań wspierających finansowo przedsiębiorstwa zagrożone Komisja stosuje również test prywatnego inwestora, a poziomem odniesienia stosowanym do oceny wszystkich rodzajów transakcji gospodarczych zawieranych przez organy publiczne są rynkowe działania. Ten poziom odniesienia stosuje się również do prywatyzacji przedsiębiorstw. Zdaniem Komisji prywatyzacja nie stanowi pomocy państwa, jeżeli jest przeprowadzana na warunkach rynkowych, a nabywca lub sprzedane przedsiębiorstwo nie otrzymuje żadnej korzyści finansowej w związku z przeprowadzoną prywatyzacją.

Test inwestora prywatnego polega tym, że porównuje się działania organów publicznych z działaniami, jakie podjąłby normalny podmiot rynkowy $\mathrm{w}$ takich samych okolicznościach. Ocena przeprowadzana na podstawie testu prywatnego inwestora uwzględnia jedynie te koszty, które zostałyby poniesione przez podmiot prywatny w takiej samej sytuacji, a nie koszty lub straty, które ponosiłoby państwo jako podmiot dysponujący środkami publicznymi.

Gdy test wykazuje, że zwykły podmiot rynkowy podjąłby te same działania co państwo, to efektem jego jest wykluczenie istnienia pomocy publicznej. Przy prywatyzacji test prywatnego inwestora przekłada się na zasadę prywatnego sprzedawcy, który sprzedając swoją firmę starałby się osiągnąć możliwie jak najwyższą cenę, unikając okoliczności, które mogłyby prowadzić do jej zaniżenia. Oznacza to również, że przy sprzedaży aktywów spółki będącej własnością państwa, państwo musi również działać jak prywatny sprzedawca, którego celem jest maksymalizacja przychodów, bądź zminimalizowanie strat ze sprzedaży. Jeśli natomiast państwo postępuje inaczej, prywatyzacja może prowadzić do rezygnacji z dochodów państwowych na rzecz nabywcy lub przedsiębiorstwa sprywatyzowanego, co w konsekwencji może stanowić pomoc państwa w rozumieniu przepisów. Często zatem współpraca z pozoru kwalifikująca się do pomocy publicznej, będzie mogła być, przy odpowiednim uzasadnieniu ekonomicznym potraktowana, jako niepodlegająca ograniczeniom wynikającym z przyznania pomocy publicznej. 
Pomoc przyznawana na ratowanie i restrukturyzację przedsiębiorstw stanowi jednocześnie najbardziej dotkliwy pod kątem reguł konkurencji środek wychodzenia przedsiębiorstwa z problemów finansowych, bo zawsze wiąże się z ograniczeniem udziału rynkowego przedsiębiorstwa ubiegającego się o taką pomoc. Zabieg ten jest dlatego dotkliwy dla przewoźnika lotniczego, że zobowiązany jest on do przekazania części opanowanego przez siebie rynku konkurentom. Wydaje się jednak, że cele tych działań restrukturyzacyjnych powinny zmierzać bardziej w kierunku „usamodzielnienia” przewoźników, tj. pozbawienia kontroli państwowej nad zarządzanym przedsiębiostwem. Tylko w takim przypadku możliwe jest bowiem zapewnienie jednakowych zachowań rynkowych. Jeśli bowiem restrukturyzacja zakłada reorganizację i i racjonalizację działalności przedsiębiorstwa dla zwiększenia skuteczności i zazwyczaj wycofanie się z działalności przynoszącej straty, to stosowanie środków kompensacyjnych w postaci rezygnacji z połączeń najbardziej dochodowych (jak w przypadku restrukturyzacji PLL LOT), zdaje się przeczyć tej idei. I z drugiej strony wzrastająca tendencja do przejmowania słabszych przewoźników przez większych konkurentów, zdaje się również podważać sens kryteriów unijnych stosowanych przy udzielaniu pomocy na ratowanie i restrukturyzację przedsiębiorstw z sektora lotniczego.

Wskazać przy tym należy, że omawiane zasady przyznawania pomocy na ratowanie i restrukturyzację nie uwzględniają specyfiki działania sektora lotniczego, bo przyjęte zostały jako założenia ogólnosektorowe.

\section{Konsekwencje prawne przyznania pomocy niezgodnej ze wspólnym rynkiem na przykładzie węgierskich linii lotniczych Malev}

W sprawie Malev Hungarian Airlines Zrt. zakwestionowana została pomoc udzielona przez państwo ${ }^{6}$. Komisja w zasadzie nie analizowała tego, czy pomoc finansowa udzielona była ze środków publicznych, bo władze węgierskie nie zakwestionowały statusu podmiotów, które udzieliły wsparcia finansowego przewoźnikowi. Każdy z nich był państwowym

\footnotetext{
${ }^{6}$ Commission Decision of $n^{\circ}$ SA. 30584 (C 38/2010, ex NN 69/2010 on the State Aid Implemented by Hungary In favour of Malev Hungarian Airlines Zrt., C(2011.) 9316.final
} 
podmiotem prawnym i jak to określiły władze węgierskie - podmioty te były „emanacją Węgier”. Państwo węgierskie nie kwestionowało również selektywności udzielonej pomocy, środki przyznane zostały bowiem na korzyść jednego przedsiębiorstwa.

Przy ocenie legalności udzielonej pomocy, Komisja praktycznie ograniczyła się do przeprowadzenia testu prywatnego inwestora. Jeszcze przed rozpoczęciem formalnego postępowania w sprawie pomocy udzielonej Malev, władze węgierskie twierdziły, że wszystkie podjęte działania zgodne były z testem prywatnego inwestora. Komisja stwierdziła, że zgodnie z ugruntowaną zasadą testu prywatnego inwestora, w przypadku gdy przedsiębiorstwo jest dokapitalizowane na warunkach lepszych niż normalnie dostępne na rynku, może to zaburzać konkurencję na rynku i mieścić się w dyspozycji art. 107(1) TFUE. Komisja musiała zatem ustalić, czy test prywatnego inwestora został przeprowadzony $\mathrm{w}$ ocenianej transakcji. Władze węgierskie w swoich komentarzach podnosiły, że różne etapy tego procesu były nierozłączne, a podjęte działania miały na celu zapewnienie funkcjonowania tej linii lotniczej poprzez znalezienie inwestora strategicznego. Z przedłożonych przez Węgry uwag wynikało w sposób oczywisty, że pomoc przyznana z korzyścią dla linii lotniczej, nie uwzględniała przyszłej rentowności tego przedsiębiorstwa i skupiała się wyłącznie na roli przewoźnika w infrastrukturze krajowej, rynku pracy i interesie dostawcy usług. Władze węgierskie przyznały również, że nie było żadnego potencjalnego prywatnego inwestora do przejęcia przedsiębiorstwa $\mathrm{w}$ takiej kondycji finansowej. W obliczu tak złych wyników finansowych notowanych od przeszło 2006 r. było jasnym, że linia lotnicza nie może prawidłowo funkcjonować bez znaczącego wsparcia finansowego dla prowadzonej działalności, a przejęcie przedsiębiorstwa przez prywatnego inwestora byłoby możliwe dopiero po przeprowadzeniu drastycznej restrukturyzacji. Komisja podkreśliła jednak, że ani Malev, ani samo państwo nigdy nie dokonały oceny przyznanej pomocy w oparciu o test prywatnego inwestora. Mając na uwadze powyższe, Komisja uznała, że w przedmiotowej sprawie działania podjęte w celu ratowania przedsiębiorstwa, przeprowadzone zostały z pominięciem testu prywatnego inwestora, a złożone wcześniej przez Węgry wyjaśnienia, potwierdziły, że wsparcie udzielone węgierskim liniom lotniczym stanowiło niedozwoloną pomoc publiczną.

W efekcie podjętej przez Komisję decyzji, Węgry zobowiązane zostały do odzyskania udzielonej przewoźnikowi pomocy, co spowodowało 
upadek węgierskiego przewoźnika lotniczego, który bez środków tych niezdolny były do dalszego funkcjonowania.

\section{Ochrona przed subsydiowaniem i nieuczciwymi praktykami przewoźników z krajów trzecich}

Sytuacja prawno-ekonomiczna przewoźników unijnych nie jest łatwa. Z jednej strony muszą oni konkurować z innymi przewoźnikami na wspólnym rynku i stosować się do tych samych reguł prawnych, a z drugiej strony konkurują z przewoźnikami spoza UE, którzy z kolei nie są związani ograniczeniami w zakresie subsydiowania działalności ze środków publicznych. Tym ostatnim praktykom miało przeciwdziałać Rozporządzenie (WE) nr 868/2004 z dnia 21 kwietnia 2004 r. w sprawie ochrony przed subsydiowaniem i nieuczciwymi praktykami cenowymi powodującymi uszczerbek dla przewoźników lotniczych Wspólnoty w świadczeniu usług lotniczych z krajów nienależących do Wspólnoty Europejskiej. Rozporządzenie przewiduje nakładanie środków rekompensujących do celów zrównoważenia subsydium przyznanego bezpośrednio lub pośrednio przewoźnikowi lotniczemu spoza UE i nieuczciwych praktyk cenowych stosowanych przez tych przewoźników. Niestety do dnia dzisiejszego rozporządzenie nie zostało zastosowane ani razu i stanowi martwą literę prawa w zapewnieniu ochrony przewoźnikom unijnym przed subsydiowaniem przewoźników z krajów trzecich. Przyczyn takiego stanu rzeczy jest kilka. Zakres stosowania tej regulacji jest bardzo wąski i nie zapewnia ochrony przewoźnikom lotniczym na trasach poza UE. Większość przewozów wykonywanych poza UE regulowana jest bilateralnymi umowami lotniczymi, a zawierane umowy horyzontalne przez UE z państwami trzecimi nie przewidują ochrony prawnej przewoźników wspólnotowych (obecnie unijnych) w tym zakresie. Ponadto przewidziana w rozporządzeniu procedura inwestygacyjna $\mathrm{w}$ przedmiocie stwierdzania istnienia nieuczciwych praktyk cenowych, czy też subsydiów, jest trudna do przeprowadzenia z uwagi na niemożność zastosowania rozporządzenia poza

7 Rozporządzenie (WE) nr 868/2004 z dnia 21 kwietnia 2004 r. w sprawie ochrony przed subsydiowaniem i nieuczciwymi praktykami cenowymi powodującymi uszczerbek dla przewoźników lotniczych Wspólnoty w świadczeniu usług lotniczych z krajów nienależących do Wspólnoty Europejskiej, Dz.Urz. UE L 162 z 30.04.2004. z 2004 r., 162/1. 
UE. Trudno jest zatem wykazać, zwłaszcza, że większość przewoźników spoza UE nie ujawnia swoich źródeł finansowania, możliwości zastosowania subwencji ze środków publicznych państwa niebędącego w UE. Brak jest zatem $\mathrm{w}$ prawie międzynarodowym skutecznego instrumentu zapewniającego równe zasady konkurowania pomiędzy przewoźnikami korzystającymi z pomocy publicznej na ratowanie i restrukturyzację $\mathrm{w}$ różnych systemach prawnych.

\section{Uwagi końcowe}

Przeprowadzone badania potwierdzają iż regulacje stwarzające możliwości finansowania przewoźników lotniczych znajdujących się w trudnej sytuacji finansowej nie są w stanie sprostać problem namnażającym się w transporcie lotniczym zwłaszcza, gdy gospodarki poszczególnych państw znajdują się na różnym poziomie rozwoju. Pogarszająca się sytuacja finansowa linii lotniczych występujących co raz częściej o pomoc na ratowanie i restrukturyzację zdaje się potwierdzać tę tezę. Z jednej strony UE dąży do zapewnienia jednakowych zasad finansowania przewoźników wewnątrz UE i poza nią, a z drugiej zdaje się być bezsilna w zapobieganiu finansowania przewoźników z krajów trzecich operujących w UE. Co ciekawe większa część tych przewoźników to przewoźnicy sieciowi zapewniający międzynarodowe połączenia komunikacyjne. Przewoźnicy niskokosztowi posiadający odmienny model biznesowy, skupiony na połączeniach point to point i maksymalnym obniżaniu standardu świadczonych usług lepiej radzą sobie z utrzymaniem rentowności Wynika to $\mathrm{z}$ pewnością z faktu, że koszty prowadzonej przez nich działalności są niższe, a siatka ich połączeń w większości ogranicza się do połączeń wewnątrzunijnych. Nie muszą zatem konkurować oni z przewoźnikami z krajów trzecich, którzy w większości mają nieograniczone możliwości finansowania prowadzonej działalności i nie wykonują połączeń wewnątrz UE.

Przeprowadzone badania aktów prawnych w zakresie finansowania linii lotniczych potwierdzają postawioną na wstępie hipotezę główną, że międzynarodowy transport lotniczy potrzebuje jasnych i jednolitych instrumentów prawnych nie tylko w odniesieniu do finansowania przewoźników lotniczych, ale międzynarodowych reguł prawnych, które za- 
pewniłyby równe zasady konkurowania dla wszystkich przewoźników z uwzględnieniem modelu biznesowego . Takie podejście wymagałoby jednak zaangażowania całej społeczności międzynarodowej. Potwierdzone zostały także hipotezy szczegółowe.

Przykład Unii Europejskiej pokazuje, że wypracowane rozwiązania regionalne nie stwarzają wystarczającej ochrony prawnej zapewniającej stabilność w funkcjonowaniu przewoźników lotniczych. Skupiają się one wyłącznie na rozwiązaniach wewnątrzunijnych zapewniających te same zasady finansowania przewoźników unijnych nie eliminując problemu głównego związanego z finansowaniem przewoźników spoza Unii.

Problem wewnątrz UE dotyczy nierównych zasad konkurowania przewoźników sieciowych i niskokosztowych i wydaje się, że polityka transportowa UE powinna dążyć do stworzenia równych zasad konkurowania pomiędzy tymi dwoma rodzajami działalności.

Słowa kluczowe: ratowanie i restrukturyzacja, obowiązek użyteczności publicznej, transport lotniczy

\section{Bibliografia}

Bujnowski M., Unijna polityka w zakresie zewnętrznych stosunków w dziedzinie lotnictwa, „Ikar” Internetowy Kwartalnik Antymonopolowy i Regulacyjny 2016, nr 2 (5),

Truxal S., Competition and Regulation in the Airline Industry: Puppets in Chaos, Routledge 2012,

Commission Decision 94/118/EC z 21 grudnia 1993r.,

Commission Decision 94/698/EC z 6 lipca 1994 r.,

Commission Decision 94/653 z dnia 27 lipca 1994r.,

Commission Decision 94/696/EC z 7 października 1994.

Commission Decision of n ${ }^{\circ}$ SA. 30584 (C 38/2010, ex NN 69/2010 on the State Aid Implemented by Hungary In favour of Malev Hungarian Airlines Zrt., C(2011.) 9316.final 


\section{AID FOR RESCUING AND RESTRUCTURING AIRLINES \\ IN DIFFICULTY - SELECTED LEGAL ISSUES}

\section{S u m m a r y}

The authors of this Article are focusing on aspects regarding state aid for rescuing and restructuring airlines in difficulty. As has been rightly stated by the authors, the EU regulations governing these issues were adopted without any divisions between specific branches of the industry. EU law which mainly governs theses aspects does not effectively protect, from a competition point of view, European airlines against such financial state grants given to airlines outside the EU. Analysis of the existing EU law conducted in this Article shows that the mentioned regulations do not include specific aspects of business models presented by airlines. According to the authors some work should be done on an international level to set up rules of competition regarding financial help for airlines in difficulty as EU regulations are not sufficient to prevent distortion in competition at the international level.

Key words: Rescuing and restructuring, public service obligation, air transport

\section{ПОМОЩЬ ДЯЯ СПАСЕНИЯ И РЕСТРОКТУРИЗАЦИИ АВИАКОМПАНИЙ, КОТОРЫЕ НАХОДЯТСЯ ПОД УГРОЗОЙ - НЕКОТОРЫЕ ЮРИДИЧЕСКИЕ ВОПРОСЫ}

$$
\text { Р е } з \text { ю м е }
$$

В статьи прописаны некоторые вопросы по поводу помощи для спасения и реструктуризации авиакомпаний, которые находятся под угрозой. Особое внимание было уделено на юридические последствия предоставление помощи не согласно с общим рынком, например, венгерские авиакомпании. Данная статья не упустила также защиту от субсидирования и недобросовестной практики перевозчиком с третьих стран. Следовательно, что проблема внутри ЕС касается неравных принципов конкуренции сетевых перевозчиков и низкостоющих, и, кажется, что транспортная политика ЕС должна идти к созданию равных принципов конкуренции между этим двумя видами деятельности.

Ключивые слова: спасение и реструктуризация, обязанность публичной пользы, воздушный транспорт 